\title{
Analysis of grey-water used for irrigating vegetables and possible effects on soils in the vicinity of Umtata Dam, Eastern Cape
}

\author{
LL Mzini $^{1 *}$ and K Winter ${ }^{2}$ \\ 'Döhne Agricultural Development Institute, Private Bag X45, Stutterheim, 4930, South Africa \\ ${ }^{2}$ Department of Environmental and Geographical Sciences, University of Cape Town, Private Bag X3, Rondebosch, 7701, South Africa
}

\begin{abstract}
In the search for alternative and reliable water sources to irrigate vegetables for backyard gardens, an experimental field was set up in the vicinity of the Umtata Dam, north-west of the town of Umtata, to test grey-water quality and its effects on soil nutrient content following 4 successive growing seasons. Samples of grey-water that were generated from informal housing adjacent to the Umtata Dam were collected from kitchen and bath tubs/washing basins. These samples were analysed before being used for irrigating vegetable crops. The results showed that grey-water quality was 'fit for purpose' for irrigating edible vegetable plants. Although the average $\mathrm{Na}^{+}(16 \mathrm{mg} / \ell)$ and $\mathrm{Cl}^{-}(15 \mathrm{mg} / \ell)$ ions were significantly higher $(p=0.05)$ for grey-water than other treatments, both were below the limit of $100 \mathrm{mg} / \ell$ set in the South African Water Quality Guidelines. The concentrations of nutrients and heavy metals found in the grey-water samples were significantly lower compared to the World Health Organization guidelines for the safe use of grey-water and within the target water quality range (TWQR) prescribed by South African guidelines for irrigation water. However, the study strongly recommends that grey-water be diluted in order to lower the salt content and to improve the irrigation water quality. Results from an analysis of soil samples showed no significant differences in $\mathrm{pH}$ as a result of applying grey-water throughout the soil profile of up to $90 \mathrm{~cm}$ depth. $\mathrm{Na}$ content of the soil irrigated with grey-water was not significantly different than that of plots where diluted grey-water and potable water were used. Therefore, the grey-water used in this study does not appear to cause an accumulation of salts and heavy metals in soil, in the short term.
\end{abstract}

Keywords: grey-water, vegetables, soil, heavy metals, $\mathrm{pH}$

\section{INTRODUCTION}

The use of untreated domestic grey-water for irrigating crops in small home gardens has several advantages (Holtzhausen, 2005; Al-Zu'bi and Al-Mohamadi, 2008). One obvious advantage is that it saves on the use of scarce freshwater resources. Studies show that supplementing irrigation sources can lead to a reduction of household potable water consumption by about $30 \%$ (Jeppesen, 1996). Further advantages, as shown in several studies, are that grey-water irrigation increases plant growth (Day et al., 1981; Rusan et al., 2007) and crop yield (Salukazana et al., 2005; Misra et al., 2009) without any effect on the quality of the crop (Day et al., 1981; Zavadil, 2009).

Environmental effects of grey-water on soils are positive and negative depending on how it is managed. For instance, in rural areas grey-water is disposed of directly on the ground near to dwelling places and often results in various health and environmental hazards such as pollution of wetlands, contamination of underground water supply and infiltration of salts, oils and grease into the soil (Van Vuuren, 2007). However, the organic matter contained in grey-water could contribute to the total loading of organic matter in the soil over time and therefore support crop production (Rusan et al., 2007). A search of the academic research literature fails to identify any studies that have determined the negative impact on soils due to irrigation of edible crops with grey-water, barring a few in which researchers discovered that irrigating with untreated wastewater elevated

\footnotetext{
To whom all correspondence should be addressed.

용 +27 43683 1240; fax: +27 43683 4930;

e-mail: loyisomzini@yahoo.com

Received 7 June 2013; accepted in revised form 7 January 2015.
}

the $\mathrm{pH}$ level by 2 to 3 units and resulted in the accumulation of heavy metals in soils to levels that were above the maximum permissible limits (MPL) according to Irish standards (Qishlaqi et al., 2008). Also, Pinto et al. (2010) discovered that electrical conductivity (EC) and soil $\mathrm{pH}$ were significantly elevated due to grey-water irrigation compared to potable and diluted grey-water (1:1) treatments. However, in the study by Rusan et al. (2007), although the accumulation of pollutants was due to grey-water irrigation, soil $\mathrm{pH}$ was not affected. Despite these reports on the accumulation of heavy metals and elevation of $\mathrm{pH}$ and EC, some findings suggest that it does not pose any risks to the health of soils (Faruqui and Al-Jayyousi, 2002; Pinto et al., 2010). Whereas, Sharvelle and co-workers (2012) investigated the effect of grey-water irrigation over the long term (more than 5 years) on landscapes, and observed accumulation of salts in soils which posed a risk to leach down to the water table. However, Sharvelle and co-workers suggested that with a sound grey-water management system, the contamination of the water table could be minimised.

For these reasons, samples of household grey-water, diluted grey-water (1:1 ratio), and potable water from a tap stand were tested. Analyses were also conducted on soils irrigated with these water treatments to determine the concentration of nutrients and heavy metals in order to establish if the use of such irrigation water might result in the accumulation of impurities in the soil.

\section{METHODOLOGY}

\section{Experimental site}

The Umtata Dam Research Station ( $31^{\circ} 30^{\prime} 04^{\prime \prime}$ S $28^{\circ} 42^{\prime} 24.5^{\prime \prime}$ ) north-west of the town Umtata, Eastern Cape Province, was 


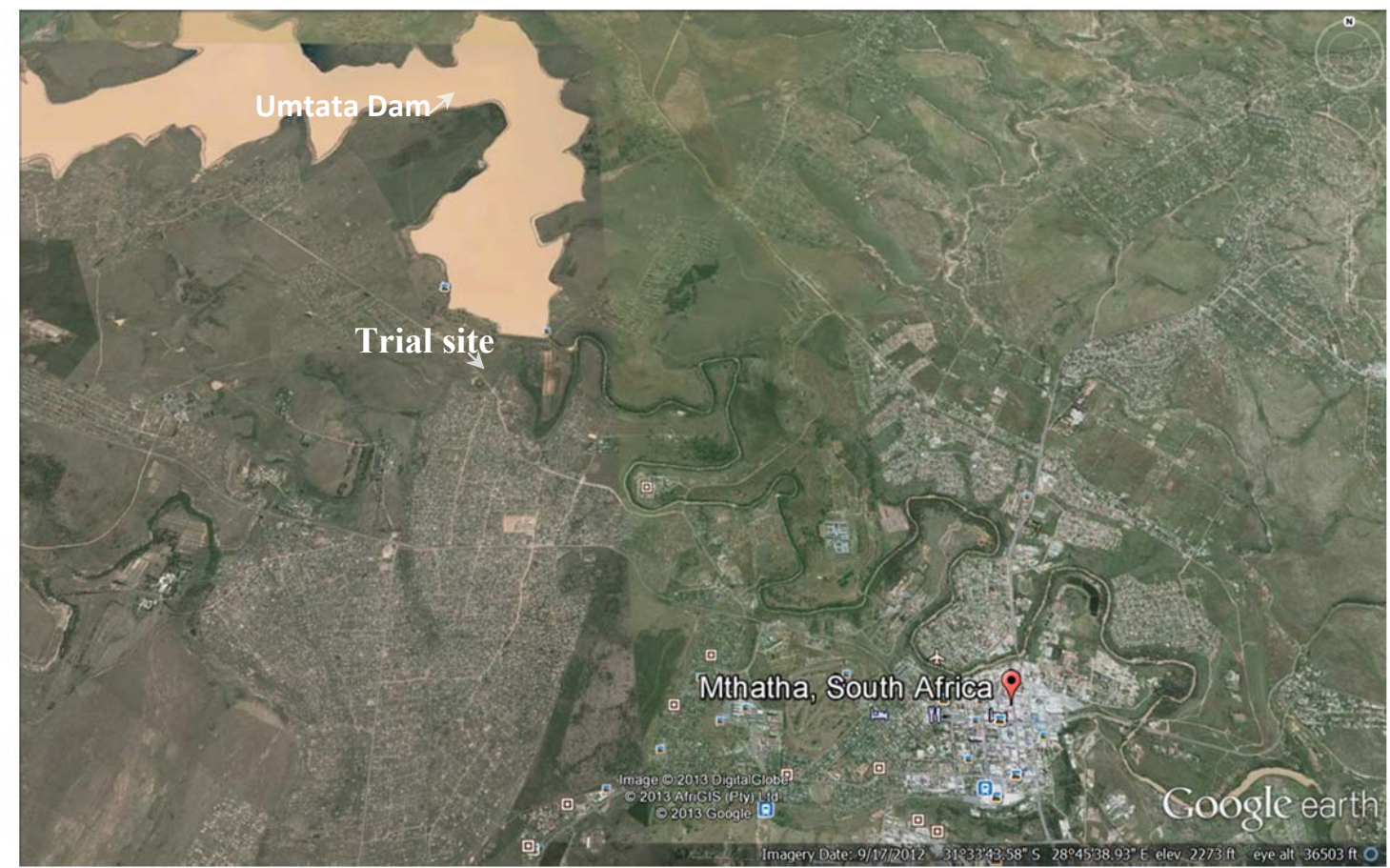

Figure 1

Location of the experimental site (Source: Google earth)

chosen as the study site (Fig. 1). This site receives between 800 and $950 \mathrm{~mm} / \mathrm{a}$ of rainfall, which falls mainly in the summer months, between October and March (Prinsloo and Schoonbee, 1984). The site is ideal for conducting a field experiment of this nature because it is managed by the Eastern Cape Provincial Department of Rural Development and Agrarian Reform, and offers a secure environment in which to conduct the experiment. In addition, low wage earners employed by the Department, being unable to afford rentals in Umtata, were allowed to build shack dwellings immediately outside the yard of the premises. Together these houses resemble a small informal settlement reflecting conditions typical of underserviced informal housing conditions in South Africa. Two tap-water stands support these 12 shack dwellings, and there are no toilet facilities. In this instance, the grey-water from this small settlement is generated mainly from the washing of clothes and bodies, and from the washing of crockery and cutlery. Waste material is collected and burnt occasionally, while for most wastewater is disposed of on the ground close to the dwellings, again typical of many informal settlements in South Africa. At the outset soil tests conducted on the soil profile classified the soils as Hutton deep red soils that are well drained and had developed from basic doleritic parent material (Soil Classification Working Group, 1991).

The study used a completely randomised design (CRD) in the layout of 3 field plots, with each of the fields receiving separate treatments, namely, potable water from a municipal tap stand, grey-water diluted with potable water (1:1), and undiluted grey-water collected from the informally constructed houses.

\section{Grey-water collection}

Grey-water samples were collected from the shack dwellings for 3 consecutive days before trial initiation. These samples were analysed for $\mathrm{pH}$ and EC using a calibrated HANNA Combo $\mathrm{pH}$ and EC, (model HI 98129) portable meter. These tests were conducted to provide an indication of the quality of grey-water as well as the volume required for daily irrigation. The mean values for $\mathrm{pH}$ and $\mathrm{EC}$, although these were inconsistent, were below $7 \mathrm{pH}$ and $\leq 25 \mathrm{mS} / \mathrm{m}$, respectively, but at an acceptable level for irrigation purposes (Bauder et al., 2014).

A total of number of 24 water samples per treatment (6 samples per season) were taken from the collection containers situated amongst the informal dwellings. In each plot a combination of a root and leafy crops were planted in each season (4 seasons in total) in the following order: cabbage and onion, spinach and beetroot, lettuce and beetroot, cabbage and onions. Data on yield and aesthetic value, chemical content and bacteria content (Enterococcus, Streptococcus and E. coli) of these vegetable crops were recorded but did not form part of the scope of the investigation reported on here.

\section{Soil sampling}

After each season, a soil auger was used to collect soil samples directly from the plots that were irrigated with potable water, diluted grey-water (grey-water diluted with potable water on 1:1 ratio) and grey-water with no dilution. A total of 32 soil samples per treatment (8 samples per season) were taken at different soil depths within each plot, namely $0-10 \mathrm{~cm}, 10-30 \mathrm{~cm}$, $30-60 \mathrm{~cm}$ and $60-90 \mathrm{~cm}$.

Afterwards, both water and soil samples were analysed in a laboratory for presence of $\mathrm{Na}, \mathrm{Fe}, \mathrm{K}, \mathrm{Mn}, \mathrm{Cu}, \mathrm{Zn}, \mathrm{Ca}, \mathrm{P}, \mathrm{Mg}$, $\mathrm{Cd}, \mathrm{Pb}, \mathrm{Ni}, \mathrm{Cr}, \mathrm{EC}$ and $\mathrm{pH}(\mathrm{KCl})$. Samples were analysed at the Döhne Laboratory in Stutterheim. Döhne Laboratory is a member of AgriLasa (Agricultural Laboratory Association of Southern Africa) and used the following techniques: (i) flame atomic absorption spectrometry to determine cations $(\mathrm{Ca}$, $\mathrm{Mg}, \mathrm{K}, \mathrm{Na}, \mathrm{Cu}, \mathrm{Mn}, \mathrm{Fe}$ and $\mathrm{Zn}$ ) and (ii) graphite furnace, for analysis of heavy metals (Cd, $\mathrm{Pb}, \mathrm{Cr}$ and $\mathrm{Ni}$ ) (Thomas 1982). The differences in water and soil parameters were compared by single-factor analysis of variance (ANOVA) with $p=0.05$ and using GenStat $12^{\text {th }}$ edition (Payne et al., 2009). 


\begin{tabular}{|l|c|c|c|c|c|}
\hline \multirow{3}{*}{ Physical properties of the soil before planting, a collective sample from all plots } \\
\hline \multirow{3}{*}{ Soil properties } & \multicolumn{5}{|c|}{ Physical properties } \\
\cline { 2 - 7 } & & \multicolumn{5}{|c|}{ Texture (\%) } \\
\cline { 2 - 7 } & Classification & Sand & Clay & Silt & $\begin{array}{c}\text { Infiltration } \\
\text { rate }(\mathrm{mm} / \mathrm{h})\end{array}$ \\
\hline Collective sample & Sandy loam & 76.6 & 14.4 & 9 & 7 \\
\hline
\end{tabular}

\begin{tabular}{|c|c|c|c|c|c|c|c|c|c|}
\hline \multicolumn{10}{|c|}{$\begin{array}{rr}\text { TABLE } 2 \\
\text { Chemical analysis of water samples taken }\end{array}$} \\
\hline \multirow[t]{2}{*}{ Treatments } & \multirow[t]{2}{*}{$\mathrm{pH}$} & \multirow{2}{*}{$\begin{array}{c}\mathrm{EC} \\
(\mathrm{mS} / \mathrm{m})\end{array}$} & $\mathrm{CaCO}_{3}$ & $\mathrm{Cl}^{-}$ & $\mathrm{HCO}_{3}^{-}$ & $\mathbf{M g}^{+}$ & $\mathrm{Na}^{+}$ & SAR & TDS \\
\hline & & & \multicolumn{7}{|c|}{$(\mathrm{mg} / \mathrm{l})$} \\
\hline $\mathrm{PW}^{\star}$ & $6.2 \mathrm{a}^{\mathrm{x}}$ & $6.0 \mathrm{c}$ & $39.5 \mathrm{a}$ & $14.0 \mathrm{ab}$ & $43.0 \mathrm{c}$ & $2.0 \mathrm{a}$ & $1.0 \mathrm{~b}$ & $0.0 \mathrm{c}$ & $50.0 \mathrm{c}$ \\
\hline $\mathrm{DGW}^{*}$ & $6.4 \mathrm{a}$ & $33.0 \mathrm{~b}$ & $1.0 \mathrm{bc}$ & $7.0 \mathrm{~b}$ & $140.0 \mathrm{~b}$ & $1.0 \mathrm{a}$ & $9.5 \mathrm{ab}$ & $1.8 \mathrm{ab}$ & $240.5 \mathrm{~b}$ \\
\hline $\mathrm{GW}^{*}$ & $6.5 \mathrm{a}$ & $50.0 \mathrm{a}$ & $2.5 \mathrm{~b}$ & $16.0 \mathrm{a}$ & $223.0 \mathrm{a}$ & $1.5 \mathrm{a}$ & $15.0 \mathrm{a}$ & $2.5 \mathrm{a}$ & $358.0 \mathrm{a}$ \\
\hline LSD (0.05) & NS & 3.513 & 12.30 & 7.026 & 27.88 & NS & 13.72 & 1.45 & 36.04 \\
\hline
\end{tabular}

${ }^{x}$ Numbers in columns with different letters are significantly different $(p \leq 0.05, L S D)$.

${ }^{*} P W$ - potable water; $D G W$ - diluted grey-water; $G W$ - grey-water.

\section{RESULTS AND DISCUSSION}

\section{Water quality analysis}

There were no observed differences in $\mathrm{pH}$ and $\mathrm{Mg}$ in each of the treatments for potable and grey-water (Table 2). However, there were significantly higher values for $\mathrm{Cl}$, EC, $\mathrm{HCO}_{3}{ }^{-}, \mathrm{Na}^{+}$, sodium adsorption ratio (SAR) and total dissolved solids (TDS) when grey-water was used in the experiment ( $p>0.05)$, and significantly higher $\mathrm{CaCO}_{3}$ hardness of the potable water. As expected, all concentrations were lower when diluted greywater was tested compared to the concentrated grey-water solution.

From these observations, grey-water contained elevated concentrations of $\mathrm{Na}^{+}(15 \mathrm{mg} / \ell)$ and $\mathrm{Cl}^{-}(16 \mathrm{mg} / \ell)$ ions although this was below the limit of $100 \mathrm{mg} / \ell$ given in the South African Water Quality Guidelines (Fatoki et al., 2002). Grey-water at pH 6.7 falls within an accepted range of $\mathrm{pH}(6.5-8.4)$ indicating the likelihood that this water is suitable for irrigation (Bauder et al., 2014). However, the elevated EC levels could increase the risk to human health, plants or soil as the observed EC was within a range of 40 to $200 \mathrm{mS} / \mathrm{m}$ (Rodda et al., 2011). An average of $50 \mathrm{mS} / \mathrm{m}$ EC was observed when grey-water was used and was recorded in the upper quartile of $70 \mathrm{mS} / \mathrm{m}$ at least once for the six samples tested.

It was surprising that although grey-water caused significantly higher bicarbonate $\left(\mathrm{HCO}_{3}^{-}\right)$concentrations, which in turn could have caused a rise in $\mathrm{pH}$, there were no significant differences in grey-water relative to other treatments with respect to the observed $\mathrm{pH} . \mathrm{HCO}_{3}-$ raises the $\mathrm{pH}$ by causing $\mathrm{Ca}^{+}$and $\mathrm{Mg}^{+}$ions to form insoluble minerals leaving $\mathrm{Na}^{+}$ion uncompetitive in the solution (Bauder et al., 2014). The presence of high-acid food, for example, tomatoes and cooking oil, in grey-water could be the cause of lower average $\mathrm{pH}$ of 6.7 (Al-Jayyousi, 2004). Tomatoes contain about 9\% citric acid, $4 \%$ malic acid and 2\% dicarboxylic acid (Petro-Turza, 1987), and cooking oil contains fatty acids (Noureddini et al., 1992).

It is interesting to note that $\mathrm{Ca}^{+}$in potable water was significantly higher and $\mathrm{Mg}^{+}$was not significantly different than in the other water treatments, which, in combination with $\mathrm{Na}^{+}$, was useful in calculating the SAR (sodium absorption ratio). Grey-water had a significantly higher SAR value of 2.5, but,

\begin{tabular}{|c|c|c|c|c|c|c|}
\hline & verage $h$ & avy met & $\begin{array}{l}\text { TABLE } \\
\text { conter }\end{array}$ & within & ter sam & ples \\
\hline Treat- & $\mathrm{Cd}$ & $\mathrm{Cr}$ & $\mathrm{Cu}$ & $\mathrm{Ni}$ & $\mathrm{Pb}$ & $\mathrm{Zn}$ \\
\hline ments & & & & & & \\
\hline PW & $0.283 \mathrm{a}^{\mathrm{x}}$ & $2.2 \mathrm{a}$ & $8.2 \mathrm{a}$ & $6.6 \mathrm{a}$ & $1.0 \mathrm{a}$ & $0.085 \mathrm{a}$ \\
\hline DGW & $0.046 \mathrm{bc}$ & $25.2 \mathrm{a}$ & $16.0 \mathrm{a}$ & $25.6 \mathrm{a}$ & $16.0 \mathrm{a}$ & $0.000 \mathrm{a}$ \\
\hline GW & $0.062 \mathrm{~b}$ & $42.2 \mathrm{a}$ & $18.8 \mathrm{a}$ & $16.4 \mathrm{a}$ & $46.0 \mathrm{a}$ & $0.000 \mathrm{a}$ \\
\hline LSD & 0.078 & N.S & N.S & N.S & N.S & N.S \\
\hline
\end{tabular}

${ }^{x}$ Numbers in columns with different letters are significantly different $(p \leq 0.05, L S D)$.

according to Gross et al. (2005), this appears not to be destructive to the environment and soil properties in the long term. Salinity of diluted grey-water in this study was lower than that of grey-water. Al-Jayyousi (2004) discovered that diluting greywater with rainwater reduces salinity caused by salts contained in food particles in grey-water. Therefore dilution of grey-water with potable water in this study helped to minimise the salinity content.

There were no significant differences in heavy metals in the water samples except in the case of Cd (Table 3). Heavy metals were much lower in concentration than that found by Surendran and Wheatly (1998) in grey-water generated from bath/shower activities. However, $\mathrm{Pb}, \mathrm{Cd}, \mathrm{Cu}$ and $\mathrm{Zn}$ were not detected in the aforementioned study from washbasin water. Since the houses where the grey-water was collected were unserviced, most grey-water was generated from the use of washbasins and kitchens, and hence $\mathrm{Zn}$ was also not detected in the current study. Water from washbasins was the least polluted compared to dishwasher and washing machine water (Friedler, 2004). $\mathrm{Zn}(0.085 \mathrm{mg} / \ell)$ levels in potable water were lower than the target water quality range (TWQR) of $1 \mathrm{mg} / \ell$ permitted by South African guidelines for irrigation (DWAF, 1996). However, $\mathrm{Pb}(46 \mathrm{mg} / \ell)$ and $\mathrm{Cu}(18.8 \mathrm{mg} / \ell)$ observed in the grey-water used in this study exceeded the permitted TWQR of $0.2 \mathrm{mg} / \ell$ (DWAF, 1996).

The overall quality of grey-water used in this study is comparable with that of the tap water used by Jackson et al. (2006) in eThekwini Municipality in the KwaZulu-Natal Province and even better than that of a tap stand in Nkonkobe Municipality in the Eastern Cape Province (Lehloesa and Muyima, 2000). 


\begin{tabular}{|c|c|c|c|c|c|c|c|c|}
\hline \multicolumn{9}{|c|}{$\begin{array}{l}\text { TABLE 4 } \\
\text { Chemical analysis of soils exposed to three different treatments: PW - potable water; } \\
\text { DGW - diluted grey-water; GW - grey-water; LSD - least significant difference }(n=32) \text {. }\end{array}$} \\
\hline \multirow[t]{2}{*}{ Treatments } & $\mathrm{pH}$ & $\mathrm{Al}$ & $P$ & $\mathrm{~K}$ & $\mathrm{Mg}$ & $\mathrm{Na}$ & $\mathrm{Ca}$ & Total cations \\
\hline & & \multicolumn{7}{|c|}{$(\mathrm{mg} / \mathrm{kg})$} \\
\hline \multicolumn{9}{|l|}{$0-10 \mathrm{~cm}$} \\
\hline PW & $5.20 \mathrm{a}^{\mathrm{x}}$ & $0.167 \mathrm{a}$ & $81 \mathrm{a}$ & $348.3 \mathrm{a}$ & $2265 \mathrm{a}$ & $72.6 \mathrm{a}$ & $365 a$ & $21.5 \mathrm{a}$ \\
\hline DGW & $5.20 \mathrm{a}$ & $0.217 \mathrm{a}$ & $68 \mathrm{a}$ & $255.7 \mathrm{~b}$ & $1283 \mathrm{bc}$ & $95.9 \mathrm{a}$ & $195 \mathrm{c}$ & $12.4 \mathrm{bc}$ \\
\hline GW & $5.73 \mathrm{a}$ & $0.183 \mathrm{a}$ & $47 \mathrm{a}$ & $236.7 \mathrm{bc}$ & $1434 \mathrm{~b}$ & $212.2 \mathrm{a}$ & $248 \mathrm{bc}$ & $13.8 \mathrm{~b}$ \\
\hline LSD & N.S & N.S & N.S & 58.04 & 744.1 & N.S & 123.9 & 6.50 \\
\hline \multicolumn{9}{|l|}{$10-30 \mathrm{~cm}$} \\
\hline $\mathrm{PW}$ & $5.33 \mathrm{a}$ & $0.217 \mathrm{a}$ & $34 \mathrm{c}$ & $202.7 \mathrm{a}$ & $1256 \mathrm{~b}$ & $73.4 \mathrm{a}$ & $268 \mathrm{a}$ & $12.4 \mathrm{a}$ \\
\hline DGW & $5.10 \mathrm{a}$ & $0.183 \mathrm{a}$ & $81 \mathrm{a}$ & $243.7 \mathrm{a}$ & $1608 \mathrm{a}$ & $118.4 \mathrm{a}$ & $239 a$ & $15.2 \mathrm{a}$ \\
\hline GW & $5.67 \mathrm{a}$ & $0.20 \mathrm{a} 0$ & $49 \mathrm{~b}$ & $205.7 \mathrm{a}$ & $1577 \mathrm{ab}$ & $328.2 \mathrm{a}$ & $270 \mathrm{a}$ & $15.0 \mathrm{a}$ \\
\hline LSD & N.S & N.S & 1.15 & N.S & 250.4 & N.S & N.S & N.S \\
\hline \multicolumn{9}{|l|}{$30-60 \mathrm{~cm}$} \\
\hline $\mathrm{PW}$ & $5.17 \mathrm{a}$ & $0.150 \mathrm{a}$ & $43.0 \mathrm{a}$ & $155.0 \mathrm{a}$ & $1925 \mathrm{a}$ & $66.3 \mathrm{a}$ & $371 \mathrm{a}$ & $18.2 \mathrm{a}$ \\
\hline DGW & $5.77 \mathrm{a}$ & $0.183 \mathrm{a}$ & $19.7 \mathrm{a}$ & $91.0 \mathrm{a}$ & $1241 \mathrm{a}$ & $125.7 \mathrm{a}$ & $180 \mathrm{a}$ & $11.5 \mathrm{a}$ \\
\hline GW & $5.80 \mathrm{a}$ & $0.150 \mathrm{a}$ & $23.3 \mathrm{a}$ & $121.3 \mathrm{a}$ & $1521 \mathrm{a}$ & $245.2 \mathrm{a}$ & $261 \mathrm{a}$ & $14.3 \mathrm{a}$ \\
\hline LSD & N.S & N.S & N.S & N.S & N.S & N.S & N.S & N.S \\
\hline \multicolumn{9}{|l|}{$60-90 \mathrm{~cm}$} \\
\hline $\mathrm{PW}$ & $5.53 \mathrm{a}$ & $0.12 \mathrm{a}$ & $35.0 \mathrm{~b}$ & $98 \mathrm{a}$ & $2396 \mathrm{a}$ & $68.3 \mathrm{a}$ & $455 \mathrm{a}$ & $22.3 \mathrm{a}$ \\
\hline DGW & $5.33 \mathrm{a}$ & $0.12 \mathrm{a}$ & $47.7 \mathrm{a}$ & $150 \mathrm{a}$ & $1794 \mathrm{~b}$ & $128.5 \mathrm{a}$ & $350 \mathrm{~b}$ & $17.0 \mathrm{~b}$ \\
\hline GW & $5.70 \mathrm{a}$ & $0.17 \mathrm{a}$ & $13.7 \mathrm{c}$ & $78 \mathrm{a}$ & $1428 \mathrm{bc}$ & $174.9 \mathrm{a}$ & $223 \mathrm{bc}$ & $13.2 \mathrm{bc}$ \\
\hline LSD & N.S & N.S & 12.44 & N.S & 423.2 & N.S & 167.2 & 3.98 \\
\hline
\end{tabular}

${ }^{x}$ Numbers in columns with different letters are significantly different $(p \leq 0.05, L S D)$.

In some cases, water from a tap stand in a rural area might not be fit to irrigate food crops due to salinity and high EC (Lehloesa and Muyima, 2000; Fatoki et al., 2003). For this reason, dilution of grey-water (with high total soluble salts) with potable water at a 1:1 ratio, as in the study by Day et al.(1981), lowered the salt content and improved water quality for irrigation purposes.

\section{Soil chemistry}

At a soil depth of 0 to $10 \mathrm{~cm}$, there was no significant difference in $\mathrm{pH}, \mathrm{Al}$ and $\mathrm{P}$ between treatments, whereas $\mathrm{K}, \mathrm{Mg}, \mathrm{Ca}$ and total cations were significantly higher in the case of the plots irrigated with potable water (Table 4). At 10 to $30 \mathrm{~cm}$ soil depth, only P and Mg were significantly higher due to diluted grey-water irrigation whereas at depths between 30 and 60 $\mathrm{cm}$ there was no significant difference between treatments for all elements. At soil depths of 60 to $90 \mathrm{~cm}, \mathrm{P}$ once again was significantly higher as a result of the diluted grey-water treatment, and $\mathrm{Mg}, \mathrm{Ca}$, and total cations were significantly elevated as a result of potable water treatment. There appeared to be no leaching of any of the measured elements from the topsoil to the lower subsoil during experiments. This was confirmed from measurement of similar $\mathrm{pH}$ values and chemical concentrations being contained within a similar range throughout the profile and across treatments.

Due to slight acidity of the grey-water used in the study, there were no significant differences observed in $\mathrm{pH}$ throughout the soil profile of 0 to $90 \mathrm{~cm}$, whereas in some other studies an increase of 1 to 2 units has been observed (Qishlaqi et al., 2008). Weil-Shafran and co-workers (2006) discovered that the $\mathrm{pH}$ of soils irrigated with grey-water was significantly lower than that of soils irrigated with potable water, and suggested that this change was probably due to enhanced bacterial activities such as respiration.

Although Na showed no significant differences between various levels within the soil profile, it was found to be almost 3 times higher for grey-water compared to soils irrigated with potable water. High Na content in the soil had the effect of disturbing the soil structure through swelling and dispersion phenomena (Halliwell et al., 2001). Bauder et al. (2014) explained this phenomenon by suggesting that $\mathrm{Ca}$ flocculate and $\mathrm{Na}$ disperses soil particles resulting in soil crusting which in turn adversely affects infiltration and permeability of water. However, in this study, soil structure after the experiment was not determined.

There was no significant difference in all heavy metal concentrations between treatments and from 0 to $90 \mathrm{~cm}$ soil depth, with the exception of $\mathrm{Cu}$ at 30 to $60 \mathrm{~cm}$ and $\mathrm{Pb}$ at 60 to $90 \mathrm{~cm}$ soil depth (Table 5). In a similar study by Al-Zu'bi and Al-Mohamandi (2008) there was no accumulation of heavy metals in the soil due to grey-water irrigation. However, Cr, although the difference was not statistically significant, was slightly elevated in the soil irrigated with grey-water, with values ranging from 28.34 to $31.66 \mathrm{mg} / \mathrm{kg}$. Kabata-Pendias and Pendias (1992) found that the range for $\mathrm{Cr}$ in soil irrigated with grey-water was between 75 and $100 \mathrm{mg} / \mathrm{kg}$, while the prescribed threshold for soil Cr in South Africa is $150 \mathrm{mg} / \mathrm{kg}$ (Herselman and Steyn, 2001). The highest Cd content obtained from diluted grey-water irrigated soils was $0.06 \mathrm{mg} / \mathrm{kg}$, far less than 3-8 mg/ $\mathrm{kg}$ which is the Cd critical soil total concentration (KabataPendias and Pendias, 1992). However, the Dutch guidelines for Cd range from 0.5 to $10 \mathrm{mg} / \mathrm{kg}$ (Mc Laughlin et al., 2000), whereas in South Africa the threshold is $2 \mathrm{mg} / \mathrm{kg}$ (Herselman and Steyn, 2001). In the current study, it was observed that the Ni level was $22.6 \mathrm{mg} / \mathrm{kg}$ in soils irrigated with grey-water, 


\begin{tabular}{|c|c|c|c|c|c|c|}
\hline \multicolumn{7}{|c|}{$\begin{array}{c}\text { TABLE 5 } \\
\text { The effect of irrigation water on soil heavy metal status ( } n=32 \text { ): PW - potable water; } \\
\text { DGW - diluted grey-water; GW - grey-water; LSD - least significant difference. }\end{array}$} \\
\hline Treatments & $Z n$ & $\mathrm{Cu}$ & $\mathrm{Cd}$ & $\mathrm{Pb}$ & $\mathrm{Ni}$ & $\mathrm{Cr}$ \\
\hline & \multicolumn{6}{|c|}{$(\mathrm{mg} / \mathrm{kg})$} \\
\hline \multicolumn{7}{|l|}{$0-10 \mathrm{~cm}$} \\
\hline $\mathrm{PW}$ & $0.767 \mathrm{ax}$ & $22.83 \mathrm{a}$ & $0.051 \mathrm{a}$ & $5.56 \mathrm{a}$ & $10.16 \mathrm{a}$ & $30.98 \mathrm{a}$ \\
\hline DGW & $0.933 \mathrm{a}$ & $21.84 \mathrm{a}$ & $0.032 \mathrm{a}$ & $5.28 \mathrm{a}$ & $4.91 \mathrm{a}$ & $28.34 \mathrm{a}$ \\
\hline GW & $1.133 \mathrm{a}$ & $22.25 \mathrm{a}$ & $0.028 \mathrm{a}$ & $5.67 \mathrm{a}$ & $14.01 \mathrm{a}$ & $31.34 \mathrm{a}$ \\
\hline LSD & N.S & N.S & N.S & N.S & N.S & N.S \\
\hline \multicolumn{7}{|l|}{$10-30 \mathrm{~cm}$} \\
\hline PW & 0.63 & $23.09 \mathrm{a}$ & $0.047 \mathrm{a}$ & $5.50 \mathrm{a}$ & $7.53 \mathrm{a}$ & $31.66 \mathrm{a}$ \\
\hline DGW & 1.03 & $21.99 \mathrm{a}$ & $0.034 \mathrm{a}$ & $5.62 \mathrm{a}$ & $8.90 \mathrm{a}$ & $29.76 \mathrm{a}$ \\
\hline GW & 1.23 & $22.31 \mathrm{a}$ & $0.034 \mathrm{a}$ & $5.59 \mathrm{a}$ & $13.46 \mathrm{a}$ & $29.70 \mathrm{a}$ \\
\hline LSD & N.S & N.S & N.S & N.S & N.S & N.S \\
\hline \multicolumn{7}{|l|}{$30-60 \mathrm{~cm}$} \\
\hline PW & $0.77 \mathrm{a}$ & $23.11 \mathrm{a}$ & $0.053 \mathrm{a}$ & $5.87 \mathrm{a}$ & $14.95 \mathrm{a}$ & $30.34 \mathrm{a}$ \\
\hline DGW & $1.07 \mathrm{a}$ & $21.04 \mathrm{c}$ & $0.066 \mathrm{a}$ & $6.09 \mathrm{a}$ & $4.03 \mathrm{a}$ & $28.90 \mathrm{a}$ \\
\hline GW & $0.57 \mathrm{a}$ & $22.43 \mathrm{ab}$ & $0.006 \mathrm{a}$ & $5.58 \mathrm{a}$ & $22.34 \mathrm{a}$ & $31.41 \mathrm{a}$ \\
\hline LSD & N.S & 1.199 & N.S & N.S & N.S & N.S \\
\hline \multicolumn{7}{|l|}{$60-90 \mathrm{~cm}$} \\
\hline PW & $0.100 \mathrm{a}$ & $21.91 \mathrm{a}$ & $0.010 \mathrm{a}$ & $5.82 \mathrm{a}$ & $9.61 \mathrm{a}$ & $29.12 \mathrm{a}$ \\
\hline DGW & $0.267 \mathrm{a}$ & $21.63 \mathrm{a}$ & $0.037 \mathrm{a}$ & $5.05 \mathrm{bc}$ & $5.43 \mathrm{a}$ & $28.54 \mathrm{a}$ \\
\hline GW & $0.133 \mathrm{a}$ & $21.41 \mathrm{a}$ & $0.008 \mathrm{a}$ & $5.09 \mathrm{~b}$ & $11.98 \mathrm{a}$ & $28.38 \mathrm{a}$ \\
\hline LSD & N.S & N.S & N.S & 0.277 & N.S & N.S \\
\hline
\end{tabular}

$x$ Numbers in columns with different letters are significantly different $(p \leq 0.05, L S D)$.

which was the highest concentration obtained amongst the treatments. Compared to other elements, $\mathrm{Ni}$ content was far less than the South African threshold of $80 \mathrm{mg} / \mathrm{kg}$ (Herselman and Steyn, 2001).

As much as grey-water might contribute to soil pollution by adding pollutants such as heavy metals, some impurities can also be added to the soil through application of inorganic fertilisers (Schroeder and Ballassa, 1963; Carnelo et al., 1997), agrochemicals such as pesticides, fungicides and herbicides (Gimeno-Garcia et al., 1996; Nicholson et al., 2003) and corrosion of metal objects such as water pipes, taps and roof materials (Boller, 1997; Sörme and Lagerkvist, 2002).

The analysis of soil profiles suggests that grey-water irrigation contributes minimally to heavy metal concentration build-up in the soil and therefore grey-water does not solely pollute the soil or pose an environmental risk to the soil within the time frame of a year.

\section{CONCLUSIONS}

The study concludes that the concentrations of nutrients and heavy metals found in the grey-water samples were significantly lower compared to the World Health Organization health guidelines for the safe use of grey-water (WHO, 2006) and were within the target water quality range (TWQR) permitted by South African guidelines for irrigation (DWAF, 1996). However, it is strongly recommended that grey-water must be diluted in order to lower the salt content and to improve the irrigation water quality so as to avoid long-term risks to the soil and the environment. Furthermore, it is recommended that grey-water and potable water dilution rates should be studied further. This study did not aim to determine optimal dilution rates other than the 1:1 ratio used.
In this study, which was conducted over a relatively shortterm period, there was no accumulation of toxins or pollutants that could contaminate the underground water since $\mathrm{pH}$ values and all other chemical elements were consistent throughout the soil profiles. Besides the foregoing, pollutants in the soil were found to be within the acceptable thresholds for South African soils (Herselman and Steyn, 2001). The study findings conclude that the use of grey-water for irrigation probably does not pose any environmental risk to soils in the short term.

\section{ACKNOWLEDGEMENTS}

The authors wish to thank the Döhne Agricultural Development Institute and Umtata Dam Research Station general and technical staff. The Eastern Cape Provincial Department of Rural Development and Agrarian Reform is gratefully acknowledged for availing its facilities.

\section{REFERENCES}

AL-JAYYOUSI O (2004) Greywater reuse: knowledge management for sustainability. Desalination 167 27-37.

AL-ZU'BI Y and AL-MOHAMAD IF (2008) Effect of greywater on soil chemical composition and yield of tomato plant. J. Food Agric. Environ. 6 (2) 408-410.

BAUDER TA, WASKOM RM, SUTHERLAND PL and DAVIS JG (2014) Irrigation: Irrigation water quality criteria. Extension no. 0.506. Colorado State University, Colorado.

BOLLER M (1997) Tracking heavy metals reveals sustainability deficit of urban drainage systems. Water Sci. Technol. 35 (9) 77-87.

CARNELO LGL, DEMINGUEZ SR and MARBAN L (1997) Heavy metals input with phosphate fertilizers used in Argentina. Sci. Total Environ. 204 (3) 245-250. 
DAY AD, McFADYEN JA, TUCKER TC and CLUFF CB (1981) Effects of municipal waste water on the yield and quality of cotton. $J$. Environ. Qual. $1047-49$.

DWAF (DEPARMENT OF WATER AFFAIRS AND FORESTRY, SOUTH AFRICA) (1996) South African Water Quality Guidelines, Field Guide. Vol. 8 ( $\left.1^{\text {st }} \mathrm{edn}\right)$. Department of Water Affairs and Forestry, Pretoria.

FARUQUI N and AL-JAYYOUSI O (2002) Greywater reuse in urban agriculture for poverty alleviation: A case study in Jordan. Water Int. 27 (3) 387-394.

FATOKI OS, LUJIZA N and OGUNFOWOKAN AO (2002) Trace metal pollution in Umtata River. Water SA 28 (2) 183-189.

FATOKI OS, GOGWANA P and OGUNFOWOKAN AO (2003) Pollution assessment in the Keiskamma River and in the impoundment downstream. Water SA 29 (2) 183-187.

FRIEDLER E (2004) Quality of individual domestic greywater streams and its implication for on-site treatment and reuse possibilities. Environ. Technol. 25 (9) 997-1008.

GIMENO-GARCIA E, ANDREU V and BOLUDA R (1996) Heavy metals incidence in the application of inorganic fertilizers and pesticides to rice farming. Environ. Pollut. 92 (1) 19-25.

GROSS A, AZULAI N, ORON G, RONEN Z, ARNOLD M and NEJIDAT A (2005) Environmental impact and health risks associated with greywater irrigation: a case study. Water Sci. Technol. 52 (8) $161-169$

HALLIWELL DJ, BARLOW KM and NASH DM (2001) A review of the effects of wastewater sodium on soil properties and their implication for irrigation systems. Aust. J. Soil Res. 39 1259-1267.

HERSELMAN JE and STEYN CE (2001) Predicted concentration of trace elements in South African soils. Report no. GREYWATER/A/2001/14. ARC Institute for Soil, Climate and Water, Pretoria.

HOLTZHAUSEN L (2005) Greywater recycling: From grey to green: Reusing greywater for food. The Water Wheel July/August 2005 $10-12$.

JACKSON S, RODDA N and SALUKAZANA L (2006) Microbiological assessment of food crops irrigated with domestic greywater. Water SA 32 (5) 700-704.

JEPPESEN B (1996) Domestic greywater reuse: Australia's challenge for the future. Desalination 106 (1-3) 311-315.

KABATA-PENDIAS A and PENDIAS H (1992) Trace Elements in Soils and in Plants ( $2^{\text {nd }}$ edn). CRC Press, Boca Raton. 75-86.

LEHLOESA LJ and MUYIMA NYO (2000) Evaluation of the impact of household treatment procedures on the quality of groundwater supplies in the rural community of the Victoria district, Eastern Cape. Water SA 26 (2) 285-290.

McLAUGHLIN MJ, HAMON RE, Mc LAREN RG, SPEIR TW and ROGERS SL (2000) Review: A bioavailability-based rationale for controlling metal and metalloid contamination of agricultural land in Australia and New Zealand. Aust. J. Soil Res. 38 (6) 1037-1086.

MISRA RK, PATEL JH and BAXI VR (2009) Removal of pollutants by tomato plants during reuse of laundry greywater for irrigation. In: International Conference on Food Security and Environmental Sustainability (FSES), 17-19 December 2009, Kharagpur, India.

NICHOLSON FA, SMITH SR, ALLOWAY BJ, CARLTON-SMITH C and CHAMBERS BJ (2003) An inventory of heavy metals inputs to agricultural soils in England and Wales. Sci. Total Environ. 311 (1-3) 205-219.

NOUREDDINI H, TEOH BC and CLEMENTS LD (1992) Densities of vegetable oils and fatty acids. J. Am. Oil Chem. Soc. 69 (12) 1184-1188.
PAYNE RW, MURRAY DA, HARDING SA, BAIRD DB and SOUTAR DM (2009) GenStat for Windows (12 ${ }^{\text {th }}$ edn) Introduction. VSN International Ltd, Hemel Hempstead.

PETRO-TURZA M (1987) Flavor of tomato and tomato products. Food Rev. Int. 2 327-328.

PINTO U, MAHESHWARI BL and GREWAL HS (2010) Effects of greywater irrigation on plant growth, water use and soil properties. Resour. Conserv. Recy. 54 (7) 429-435.

PRINSLOO JF and SCHOONBEE HJ (1984) Observation of fish ponds at the Umtata Dam Fish Research Centre, Transkei. Part 1: The use of pig manure with and without pelleted fish feed. Water SA 10 (1) $15-23$.

QISHLAQI A, MOORE F and FORGHANI G (2008) Impact of untreated wastewater on soils and crops in Shiraz suburban area, SW Iran. Environ. Monit. Assess. 141 (1-3) 257-273.

RODDA N, SALUKAZANA L, JACKSON SAF and SMITH MT (2011) Use of domestic greywater for small scale irrigation of food crops: Effects on plants and soil. Phys. Chem. Earth 36 1051-1062.

RUSAN MJM, HINNAWI S and ROUSAN L (2007) Long term effect of wastewater irrigation of forage crops on soil and plant quality parameters. Desalination 215 143-152.

SALUKAZANA L, JACKSON S, RODDA N, SMITH M, GOUNDEN T, MCLOED N and BUCKLEY C (2005) Re-use of greywater for agricultural irrigation. Paper presented at the $3^{\text {rd }}$ International Conference of Ecological Sanitation, 23-26 May 2005, Durban, South Africa.

SCHOERDER H and BALASSA JJ (1963) Cadmium: Uptake by vegetables from superphosphate in soil. Science 140 (3568) 819-820.

SHARVELLE S, ROESNER L, QIAN Y, STOMBERGER M and AZAR MN (2012) Long-term study on landscape irrigation using household graywater - Experimental study. The Urban Water Centre, Colorado State University. URL: http://www.aciscience.org/docs/ graywater\%20report\%202012.pdf (Accessed 6 June 2014).

SOIL CLASSIFICATION WORKING GROUP (1991) Soil Classification: A Taxonomic System for South Africa. Department of Agricultural Development, Pretoria.

SÖRME L and LAGERKVIST R (2002) Sources of heavy metals in urban wastewater in Stockholm. Sci. Total Environ. 298 (1-3) 131-145.

SURENDRAN S and WHEATLEY AD (1998) Grey-water reclamation for non-potable re-use. Water Environ. J 12 406-413.

THOMAS GW (1982) Exchangeable cations. In: Page AL (ed) Methods of Soil Analysis. Part 2 (2nd edn) Agron. Monogr. 9. ASA and SSSA, Madison, Wisconsin. 159-165.

VAN VUUREN L (2007) Community health: Household wastewater still a grey area. The Water Wheel November/December 2007 20-22.

WEIL-SHAFRAN A, RONEN Z, WEISBROD N, ADAR E and GROSS $M$ (2006) Potential changes in soil properties following irrigation with surfactant-rich greywater. Ecol. Eng. 26 348-354.

YILMAZ E, TANDON KS, SCOTT JW, BALDWIN EA and SHEWELT RL (2001) Absence of a clear relationship between lipids pathways enzymes and volatile compounds in fresh tomatoes. J. Plant Physiol. 158 1111-1116.

WHO (2006) Guidelines for the Safe use of Wastewater, Excreta and Greywater. Volume 2: Waste Water in Agriculture. WHO, Geneva. 177-182.

ZAVADIL J (2009) The effect of municipal wastewater irrigation on the yield and quality of vegetables and crops. Soil Water Res. 4 (3) 91-103. 